\title{
Peningkatan Kualitas Citra Reduksi Noise Menggunakan Iterative Denoising and Backward Projection-CNN dan TFM-CLAHE pada Citra 24 Bit
}

Improvement of Quality of Image Noise Reduction using Iterative Denoising and Backward Projection-CNN and TFM-CLAHE on 24 Bit Image

\author{
Irpan Adiputra Pardosi ${ }^{1}$, Hernawati Gohzali ${ }^{2}$ \\ ${ }_{1,2}$ Departemen Teknik Informatika, STMIK Mikroskil Medan \\ E-mail: ${ }^{1}$ irpan@mikroskilac.id, ${ }^{2}$ hernawati.gohzali@mikroskil.ac.id
}

\begin{abstract}
Abstrak
Penurunan kualitas yang diakibatkan adanya noise atau kontras yang tidak normal pada citra mengakibatkan objek pada citra menjadi tidak jelas. Masalah itu dapat disebabkan perangkat yang digunakan menimbulkan noise atau tidak bisa menghasilkan kontras yang normal. Adanya noise dan kontras rendah gelap berdampak besar terhadap kualitas citra, proses reduksi noise yang berukuran besar $45 \%$ akan berpengaruh pada informasi didalam citra sehingga kualitas citra hasil reduksi menjadi hal yang perlu dipertimbangkan untuk noise berukuran besar. Penelitian tahun 2019 menggunakan algoritma Iterative Denoising and Backward Projections with CNN (IDBPCNN) dinyatakan mampu mereduksi noise hingga 51\% dengan kualitas PSNR diatas $30 \mathrm{~dB}$ dengan mengabaikan kontras dari citra. Sedangkan algoritma untuk meningkatkan kontras citra menggunakan algoritma Triangular Fuzzy Membership-Contrast Limited Adaptive Histogram Equalization (TFM-CLAHE) juga diklaim mampu meningkatkan kontras citra dengan kualitas PSNR di atas $20 \mathrm{~dB}$, yang lebih baik dibandingkan dengan algoritma CLAHE. Berdasarkan hasil pengujian yang dilakukan pada 10 citra kontras rendah gelap dengan noise $45 \%$ didapatkan kombinasi algoritma TFM-CLAHE diikuti IDBP-CNN lebih baik dengan rata-rata hasil PSNR = $31.69 \mathrm{~dB}$, dibandingkan sebaliknya PSNR $=31.01 \mathrm{~dB}$, Namun rata-rata keragaman informasi citra hasil dengan kombinasi IDBP-CNN diikuti TFM-CLAHE lebih kecil selisihnya terhadap citra asli berdasarkan Shanon Entropy sebesar 3.77\% dibandingkan sebaliknya 4.75\%
\end{abstract}

Kata kunci: kontras rendah, noise salt, TFM-CLAHE, IDBP-CNN, kualitas citra

\begin{abstract}
Decreasing quality because of noise or abnormal contrast in images impacted objects become unclear. These problems can be caused the device is create some noise or can't produce normal contrast. The presence of noise and low dark contrast has a major impact on image quality, the large noise reduction $45 \%$ affected information in image, so quality of the reduced image becomes something that needs to be considered for large noise. In 2019 a study using Iterative Denoising and Backward Projections with CNN (IDBP-CNN) algorithm was stated able to reduce noise up to $51 \%$ with PSNR above $30 \mathrm{~dB}$ by ignoring the contrast of the image. Meanwhile, Triangular Fuzzy Membership-Contrast Limited Adaptive Histogram Equalization (TFM-CLAHE) algorithm is claimed able to increase image contrast with PSNR quality above $20 \mathrm{~dB}$, which is better than CLAHE algorithm. Based of the tests carried out on 10 dark low-contrast images with $45 \%$ noise, combination of TFM-CLAHE algorithm and IDBP-CNN is better with an average $P S N R=31.69 \mathrm{~dB}$, compared to opposite PSNR $=31.01 \mathrm{~dB}$, but the average diversity of information the resulting image with combination IDBP-CNN and TFM-CLAHE is less difference than original image based on SE $3.77 \%$ compared to other is $4.75 \%$
\end{abstract}

Keywords: low contrast, salt noise, TFM-CLAHE, IDBP-CNN, images quality 


\section{PENDAHULUAN}

Peningkatan kualitas citra setelah mereduksi noise dan meningkatkan kontras citra akan berdampak pada perubahan keberagaman informasi di dalam citra, hasil yang berbeda juga didapatkan untuk citra berkontras rendah [1][2]. Penurunan kualitas yang diakibatkan adanya derau (noise) atau kontras yang tidak normal pada citra mengakibatkan objek di dalam citra menjadi tidak jelas[3] hal ini bisa disebabkan banyak hal seperti perangkat yang digunakan menimbulkan noise atau tidak dapat menghasilkan kontras yang normal atau bisa juga terjadi pada saat proses pengiriman citra melalui jaringan terjadi penurunan kualitas akibat adanya kompresi pada citra [4]. Noise salt and pepper merupakan noise yang sering disolusikan namun kontras rendah juga berdampak besar terhadap kualitas citra [5][6], proses reduksi noise yang berukuran besar berpengaruh pada informasi citra sehingga kualitas citra hasil reduksi menjadi hal yang perlu dipertimbangkan untuk noise berukuran besar [7]. Permasalahan citra yang memiliki noise dan juga berkontras rendah pada akhirnya menjadi hal yang penting untuk disolusikan, supaya proses pengolahan data pada citra tidak terhambat untuk tahap selanjutnya baik untuk identifikasi objek, pengenalan pola atau tujuan lainnya.

Penelitian yang relevan untuk proses reduksi noise dengan persentasi penyebaran noise sebesar 45\% menggunakan algoritma Adaptive Fuzzy Filter (AFF) didapatkan hasil PSNR 28.10 $\mathrm{dB}$ [7] masih di bawah kualitas citra yang baik yaitu $30 \mathrm{~dB}$ [8]. Namun, tahun 2019 penelitian menggunakan algoritma Iterative Denoising and Backward Projections with CNN (IDBP-CNN) dinyatakan mampu mereduksi noise hingga 51\% namun dengan kualitas citra hasil berdasarkan nilai PSNR hingga diatas $30 \mathrm{~dB}$, dengan pengujian yang dilakukan mengabaikan kontras dari citra [9]. Sedangkan algoritma untuk meningkatkan kontras citra menggunakan algoritma Gradient Based Low Light Image Enhancement dengan hasil kemiripan citra hasil dengan citra asli hingga SSIM 7.0077, namun dampak dari implementasi pada citra kontras rendah justru menimbulkan noise pada citra hasil dan ketika dilakukan proses berulang kualitas citra hasil semakin menurun[10]. Selain itu penelitian lain mengimplementasikan algoritma peningkatan kontras menggunakan algoritma Triangular Fuzzy Membership-Contrast Limited Adaptive Histogram Equalization (TFM CLAHE) yang diklaim mampu meningkatkan kontras citra dengan kualitas PSNR di atas $20 \mathrm{~dB}$, yang lebih baik dibandingkan dengan algoritma Histogram Equalization (HE), Adaptive HE (AHE), Contrast Limited AHE (CLAHE) [11][12], kedua algoritma perbaikan kualitas citra mampu menghasilkan citra dengan kualitas PSNR diatas $30 \mathrm{~dB}$.

Penelitian ini akan menerapkan algoritma IDBP-CNN untuk mereduksi noise salt and pepper dengan persentase sebesar 45\% dengan menggunakan nilai Threshold $=192$ untuk acuan proses perulangan iterasi reduksi noise[13] dan algoritma TFM-CLAHE digunakan untuk memperbaiki kontras dari citra kontras rendah yang gelap, setelah kedua algoritma diimplementasikan tujuan utama dalam penelitian ini untuk mendapatkan kombinasi paling optimal antara proses reduksi noise (IDBP-CNN) dan perbaikan kontras (TFM-CLAHE) untuk meningkatkan kualitas citra hasil berdasarkan nilai MSE dan PSNR, selain itu kualitas citra hasil juga, untuk mengetahui persentase keragamaninformasi pada citra hasil dibandingkan citra asli dengan metode shanon entropy setelah dilakukan kedua proses perbaikan kualitas citra.

\section{METODE PENELITIAN}

\subsection{Tahapan Penelitian}

Pada tahapan penelitian Gambar 1 di bawah, digambarkan untuk proses peningkatan kualitas citra dimulai dengan akuisisi citra kemudian dilakukan pra-processing meliputi penambahan citra noise pada citra kontras rendah gelap dengan langkah berikut:[14]

1. Menghitung jumlah noise $=45 \% *$ Lebar Citra $*$ Tinggi Citra $/ 100$

2. Ambil nilai piksel secara acak dari dalam citra berdasarkan lebar dan tinggi citra lalu konversi menjadi grayscale; piksel $=(\mathrm{R}+\mathrm{G}+\mathrm{B}) / 3$; 
3. Jika piksel $>128$ set jadi nilai warna hitam (0), sebaliknya set jadi warna putih (255)

4. Langkah 2 dan 3 diulangin sebanyak noise.

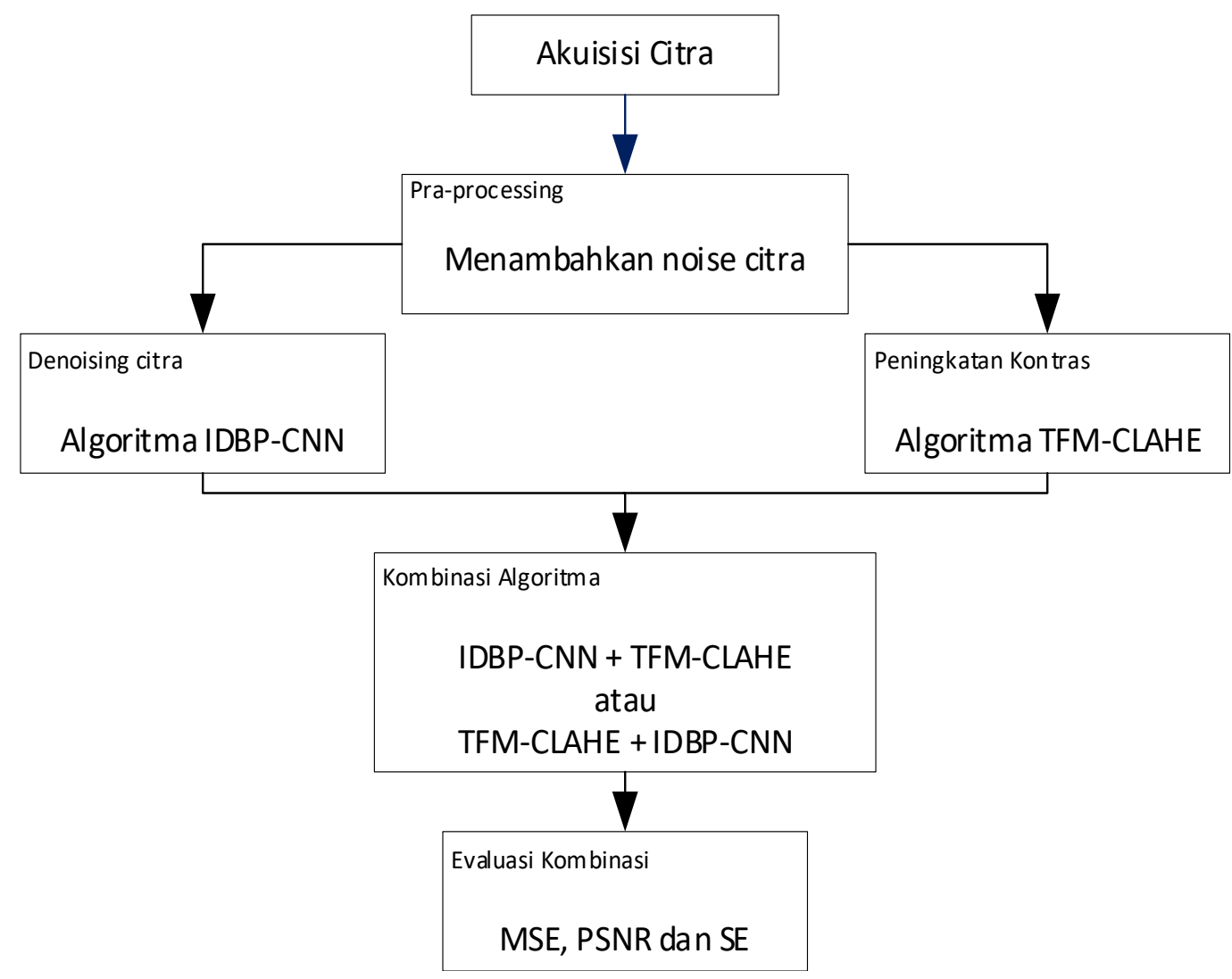

Gambar 1 Model Tahapan Penelitian

Setelah itu proses dilanjutkan dengan memperbaiki kontras atau denoising (pilih salah satu) lalu menggabungkan kedua algoritma dalam satu citra hasil yaitu kombinasi Denoising + Perbaikan Kontras (IDBP-CNN + TFM-CLAHE) atau Perbaikan Kontras + Denoising (TFMCLAHE+IDBP-CNN). Selanjutnya kualitas citra hasil diukur menggunakan metode Mean Square Error (MSE) dan Peak Signal Noise Ratio (PSNR) untuk mendapatkan kualitas citra hasil dan metode Shannon Entropy (SE) untuk mengetahui perubahan informasi di dalam citra setelah proses perbaikan citra untuk kedua kombinasi algoritma dilakukan.

\subsection{Algoritma Iterative Denoising and Backward Projections (IDBP) with CNN}

Metode Iterative Denoising and Backward Projections merupakan sebuah metode iteratif sederhana untuk menyelesaikan problema invers linier dengan menggunakan algoritma denoising, yang menyediakan sebuah alternatif untuk metode Plug-and-Play (P\&P). Bedanya pada metode ini memerlukan parameter yang lebih sedikit dan jumlah iterasi yang lebih sedikit daripada metode $P \& P$. Pseudocode dari metode Iterative Denoising and Backward Projections with CNN dapat dirincikan sebagai berikut: [13]

Input: $\quad H, y, \sigma_{e}$, operator denoising $\mathcal{D}(; \sigma)$, kriteria berhenti, $y=H_{x}+e$, sedemikian sehingga $\mathrm{e} \sim \mathcal{N}\left(0, \sigma_{e}^{2} I_{m}\right)$ dan $x$ adalah sebuah sinyal tidak dikenal dimana modelnya dispesifikasikan oleh $\mathcal{D}(\because \sigma)$

Output: $\quad \chi$ adalah estimasi dari $\mathrm{x}$ 
Inisialisasi: $\mathrm{y}_{0}=$ inisialisasi awal, $\mathrm{k}=0$, persyaratan $\delta$.

while $\{$ kriteria berhenti belum tercapai $\}$ do

$k=k+1$

$\tilde{x}_{k}=\mathcal{D}\left(\tilde{y}_{k}-1 ; \sigma_{e}+\delta\right)$;

Menerapkan proses single $D N N$ (Konvolusi+Re-LU) untuk setiap proses invers, tanpa memodifikasi $\delta$ selama iterasi untuk mendapatkan nilai $\tilde{x}_{k}[13]$

end

$$
\widetilde{\mathcal{Y}}_{k}=H^{\dagger} y+\left(I_{n}-H^{\dagger} H\right) \tilde{x}_{k} ;
$$

$\widehat{x}=\tilde{x}_{k}$

Keterangan:

$\mathrm{D}$ = fungsi operator denoising

$\mathrm{H}=$ matriks degradasi $\mathrm{m} \times \mathrm{n}$

$\mathrm{H}^{\dagger}=$ pseudo invers dari matriks $\mathrm{H}$

$\chi=$ warna piksel citra hasil restorasi

$\chi_{\mathrm{k}}=$ warna piksel citra hasil restorasi untuk iterasi ke-k

$\mathrm{y}=$ warna piksel citra yang sedang diamati

$\mathrm{y}_{\mathrm{k}}=$ warna piksel citra untuk pengamatan berikutnya

$\delta=$ parameter persyaratan

$\sigma_{\mathrm{e}}=$ standar deviasi

$\mathrm{I}_{\mathrm{n}}=$ matriks dengan ukuran $\mathrm{n} \times \mathrm{n}$

Algoritma Iterative Denoising and Backward Projections memerlukan input berupa operator denoising dan kriteria berhenti. Output dari algoritma ini adalah nilai estimasi untuk setiap piksel x pada citra digital yang dimasukkan. Proses kerja dari algoritma ini akan menghitung estimasi setiap nilai piksel berdasarkan nilai piksel sebelumnya. Proses ini akan diulangi hingga kriteria berhenti tercapai.[13]

\subsection{Mean Absolute Gradient (MAG)}

Untuk mengklasifikasikan piksel corrupted atau tidak, akan digunakan metode Mean Absolute Gradient (MAG). MAG yang kecil mengindikasikan sebuah daerah datar dan MAG yang besar biasanya mengindikasikan daerah kompleks atau daerah impulse noise. MAG dapat didefinisikan sebagai berikut:

$$
M A G=\frac{1}{N-1} \sum_{i=0}^{n-1} F(0)-F(i)(4)
$$

dimana $\mathrm{F}(\mathrm{i})$ melambangkan nilai intensitas dari piksel pada sebuah region. $\mathrm{N}$ adalah total piksel pada region. $F(0)$ adalah intensitas dari piksel pada bagian tengah seperti terlihat pada gambar berikut: [3]

$$
\begin{gathered}
\begin{array}{|l|l|l|}
\hline & & \\
\hline & \mathrm{F}(0) & \\
\hline & & \\
\hline
\end{array} \\
z_{i j}= \begin{cases}1 & M A G>T \\
1 & x_{i j}=0 \\
1 & x_{i j}=255 \\
0 & M A G \leq T\end{cases} \\
\end{gathered}
$$


Sebuah nilai threshold $\mathrm{T}$ dapat ditentukan berdasarkan hasil pengujian. Jika $Z_{i j}=1$, maka piksel $x_{i j}$ akan ditandai sebagai k1andidat noise, jika tidak, berarti $x_{i j}$ tidak memiliki noise[5]

\subsection{Metode CLAHE}

CLAHE merupakan teknik perbaikan kontras citra dengan meningkatkan kontras lokal citra. Lokal citra ini didapat dengan membentuk beberapa grid simetris pada citra yang disebut dengan region size. Struktur regional citra dibagi menjadi tiga, yaitu bagian yang berada di sudut citra ditandai dengan corner region (CR), bagian tepi kecuali CR ditandai dengan border region (BR), dan bagian lainnya yang berada di tengah ditandai dengan inner region (IR). Permasalahan peningkatan kontras yang berlebihan dapat diatasi dengan menggunakan Contrast Limited Adaptive Histogram Equalization (CLAHE), yaitu dengan memberikan nilai batas pada histogram. Nilai batas ini disebut dengan clip limit yang menyatakan batas maksimum tinggi suatu histogram. Cara menghitung clip limit suatu histogram dapat didefinisikan dengan persamaan[11]:

$$
\beta \frac{M}{N}\left(1+\frac{\alpha}{100}\left(S_{\max }-1\right)\right)
$$

dimana:

$\mathrm{M}=$ Luas region size

$\mathrm{N}=$ Nilai grayscale $(256)$

$\alpha=$ Clip factor (penambah batas limit suatu histogram yang bernilai antara 0 s.d 100)

$S_{\max }=$ nilai maksimum dari warna piksel

\subsection{Metode TM-CLAHE}

Metode TFM-CLAHE pengembangan dari metode CLAHE yang menerapkan fungsi keanggotaan segitiga fuzzy (triangular fuzzy membership / TFM) untuk menentukan parameter clipping secara otomatis yang membatasi tingkat kontras pada sebuah citra, sehingga menghasilkan sebuah citra yang telah ditingkatkan kontrasnya. Parameter clipping yang diperoleh akan berbeda-beda, tergantung pada citra input yang dimasukkan [11]. Metode TFM-CLAHE menyediakan fungsi fuzzy untuk membatasi clipping secara otomatis dan berbeda-beda untuk setiap citra. Fungsi TFM mengambil tiga buah nilai sebagai input yang membentuk nilai minimum, maksimum dan ratarata (mean) dari intensitas piksel citra pada sebuah window dan menghitung nilai fuzzy $\mu_{1}\left(\operatorname{Pr}_{\beta}\right)$ yang menentukan parameter clipping untuk citra I. Nilai-nilai ini akan menjadi input untuk parameter $\mathrm{a}, \mathrm{b}$ dan $\mathrm{c}$ dari fungsi keanggotaan segitiga. Nilai yang dihasilkan oleh TFM berkisar antara 0 dan 1 dan clipping akan dilakukan berdasarkan nilai tersebut. Nilai intensitas yang melebihi batasan clipping yang dihasilkan kemudian akan didistribusikan ulang sama seperti proses pada CLAHE, sehingga diperoleh histogram yang lebih halus[11]. Nilai fuzzy segitiga yang dihasilkan oleh fungsi keanggotaan akan disimbolkan dengan $\mathrm{TM}=(\mathrm{a}, \mathrm{b}, \mathrm{c})$. Rumusan matematis dari TFM dapat dilihat pada rumusan berikut:

$$
\mu_{1}\left(\operatorname{Pr}_{\beta}\right)=\left\{\begin{array}{cl}
0 & \operatorname{Pr}_{\beta}<a \\
\frac{P r_{\beta}-a}{b-a} & a \leq P r_{\beta} \leq b \\
\frac{C-P r_{\beta}}{c-b} & b \leq P r_{\beta} \leq c \\
0 \quad P r_{\beta}>c &
\end{array}\right.
$$


Dimana: parameter $\{\mathrm{a}, \mathrm{b}, \mathrm{c}\}$ (dengan $\mathrm{a}<\mathrm{b}<\mathrm{c}$ ) menentukan koordinat $\mu_{1}\left(\operatorname{Pr}_{\beta}\right)$ dari tiga sudut TFM. Disini $\mu_{1}\left(\operatorname{Pr}_{\beta}\right)$ melambangkan parameter clipping citra. Titik $\mathrm{b}$ dengan nilai keanggotaan maksimal sebesar 1 , adalah nilai rata-rata serta a dan $\mathrm{c}$ adalah nilai spread kiri dan kanan dari $\operatorname{Pr}_{\beta}[11]$

2.6 Metode Pengukuran kualitas citra dan keberagaraman informasi

a) Peak Signal To Noise Ratio (PSNR)

PSNR digunakan untuk mengetahui perbandingan dari kualitas citra sebelum dan setelah disisipkan pesan ke dalam citra tersebut. PSNR biasanya diukur dalam satuan desibel (dB). Setelah dihitung nilai MSE, nilai PSNR dapat dihitung dengan rumus berikut:[15]

$\mathrm{L}=$ Nilai maksimum piksel

$$
P S N R=10 * \log _{10}\left(\frac{L^{2}}{M S E}\right)
$$

b) Mean Square Error (MSE)

MSE digunakan untuk mengetahui perbedaan error antara citra stego-image dan coverimage. Nilai MSE selalu berbanding terbalik dengan Nilai PSNR. Jika nilai MSE kecil maka akan menghasilkan nilai PSNR yang besar dan begitu sebaliknya. Biasanya nilai MSE diukur dalam satuan persen (\%). Untuk menghitung nilai MSE dapat dilihat pada rumus berikut:[15]

$$
M S E=\frac{1}{M \times N} \sum_{i=1}^{M} \sum_{j=1}^{N}(f(i, j)-g(i, j))^{2}
$$

$\mathrm{M}=$ Panjang dari citra (dalam piksel)

$\mathrm{N}=$ Lebar dari citra (dalam piksel)

$\mathrm{f}(\mathrm{i}, \mathrm{j})=$ Nilai dari kordinat piksel citra sebelum disisipkan pesan

$g(i, j)=$ Nilai dari kordinat piksel citra setelah disisipkan pesan

c) Shannon Entropy (SE)

SE merupakan rumus matematika yang digunakan untuk menghitung keragaman atau kekayaan informasi. Semakin tinggi nilai SE maka semakin tinggi pula detail dan informasi yang dimiliki oleh citra tersebut. Rumus SE dinyatakan di bawah ini[15]

$$
E=-\sum_{i=0}^{N} r(i) \log _{2} r(i)
$$

$\mathrm{r}(\mathrm{i})=$ Probabilitas kemunculan nilai keabuan

$\mathrm{N}=$ Nilai keabuan tertinggi

\section{HASIL DAN PEMBAHASAN}

Pengujian kedua algoritma dilakukan pada 10 buah citra warna RGB 24 bit berekstensi .jpg yang bersumber dari website https://www.piqsels.com/ yang dipilih dengan berbagai variasi warna dan objek dengan kontras normal. Citra kontras normal tersebut diproses 
menjadi citra kontras rendah gelap menggunakan aplikasi Photoshop dengan membuat pengaturan brightness/contrast menjadi minimum (gelap). Citra kontras rendah gelap ini pada masing-masing citra ditambahkan noise sebanyak $45 \%$ menggunakan program seperti terlihat pada Gambar 3 di bawah[14].

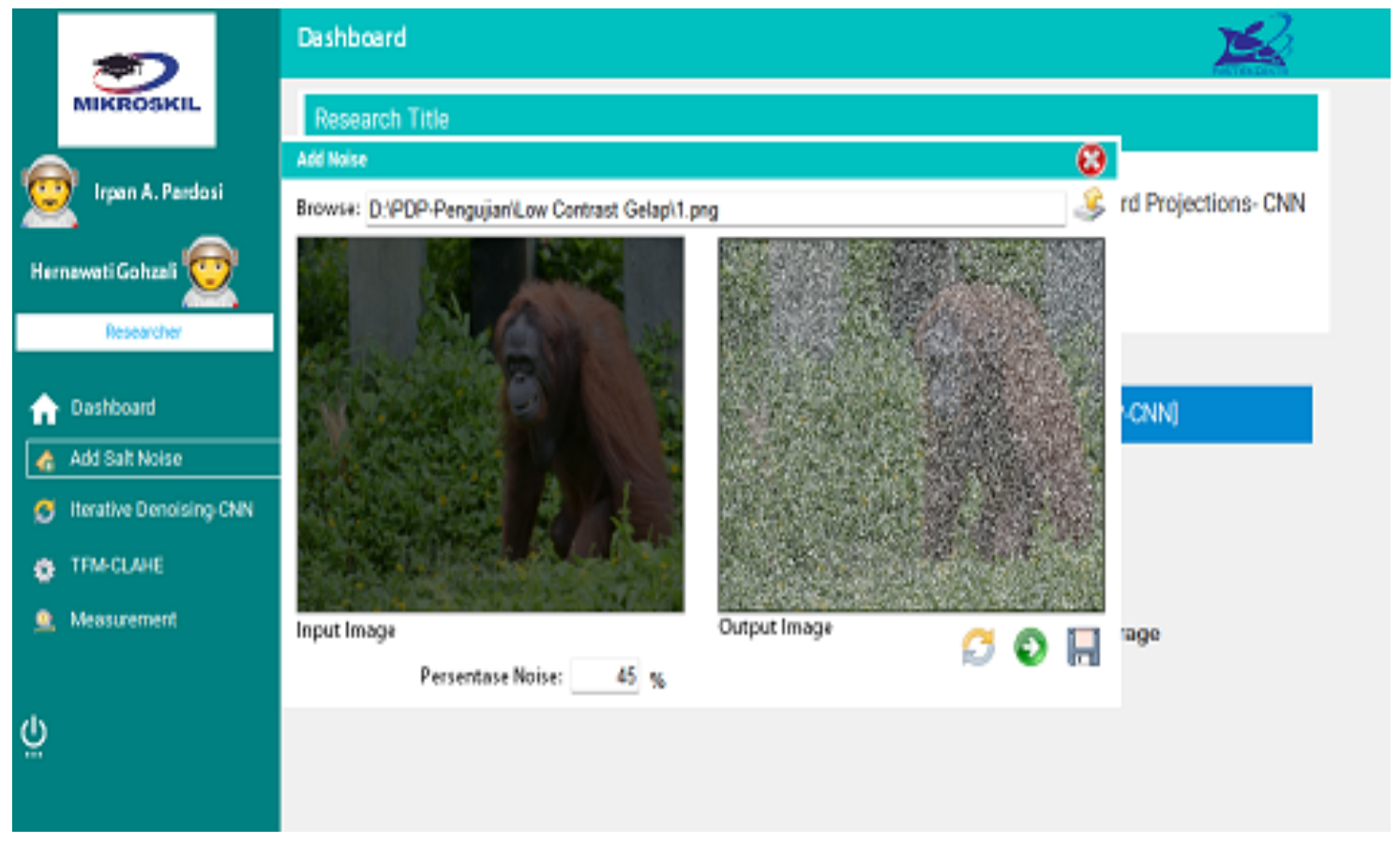

Gambar 3 Proses menambahkan noise pada citra kontas gelap

Setelah diproses seperti tahapan di atas, tampilan dari dataset sebanyak 10 citra uji dari masing-masing yang digunakan pada penelitian ini dijabarkan pada Tabel 1 di bawah.

Tabel 1 Dataset citra yang digunakan pada pengujian

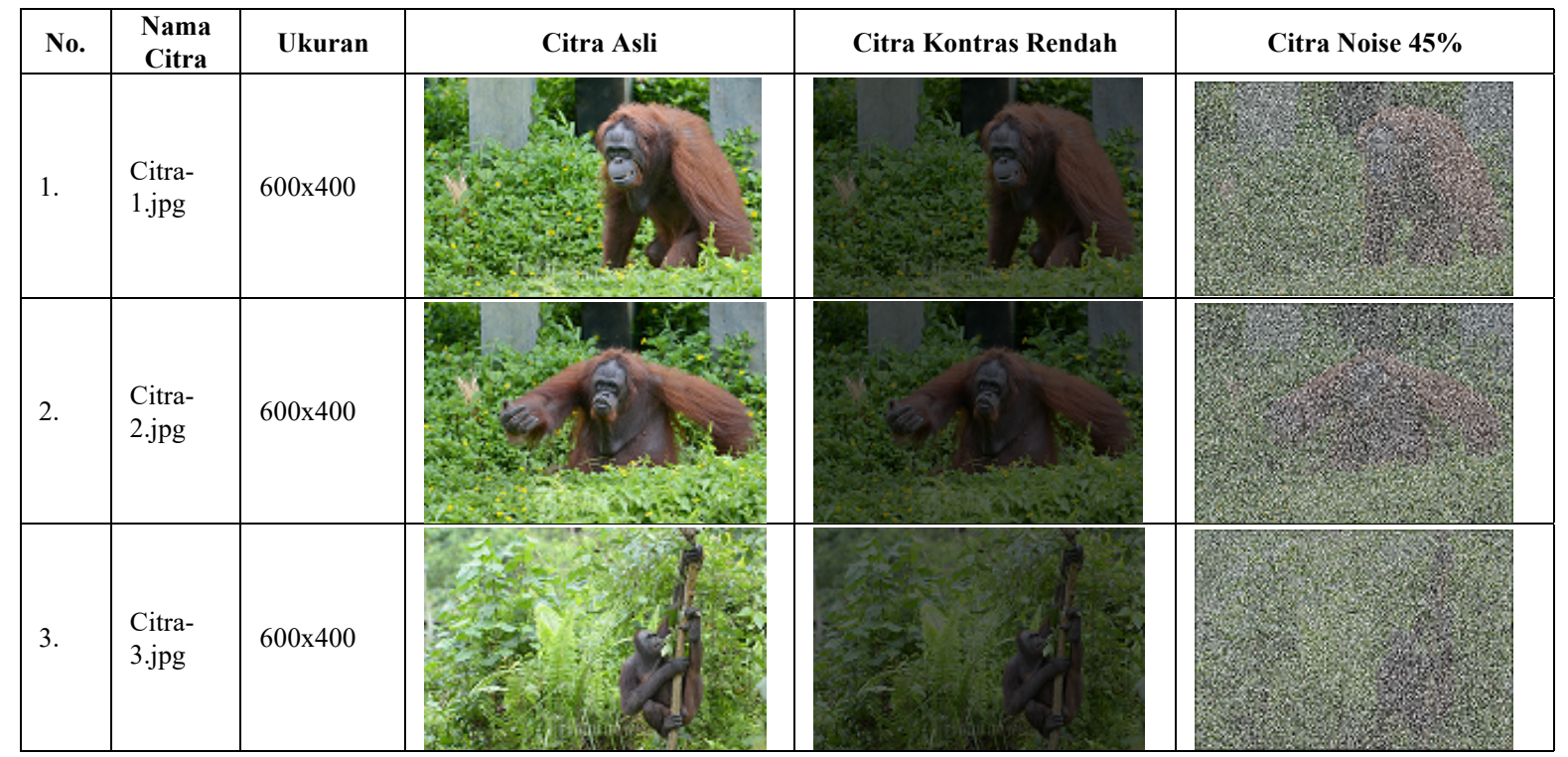


Techno.COM, Vol. 20, No. 4, November 2021: 566-579

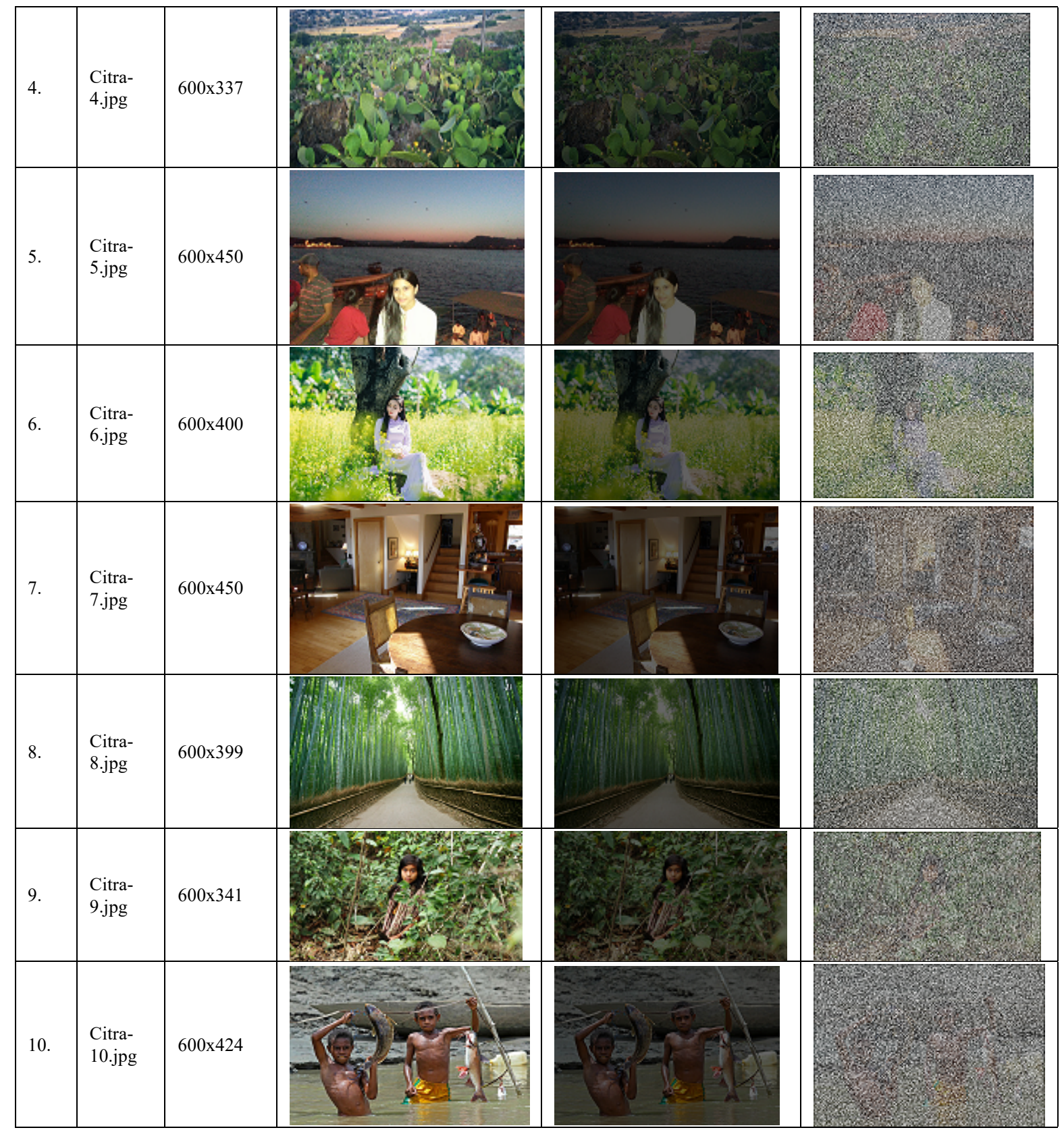

Setelah dataset sudah selesai diproses, tahapan berikutnya untuk menigkatkan kualitas citra dengan algoritma $I D B P-C N N$ dan TFM-CLAHE dengan urutan proses seperti ditampilkan pada Gambar 4 di bawah. 


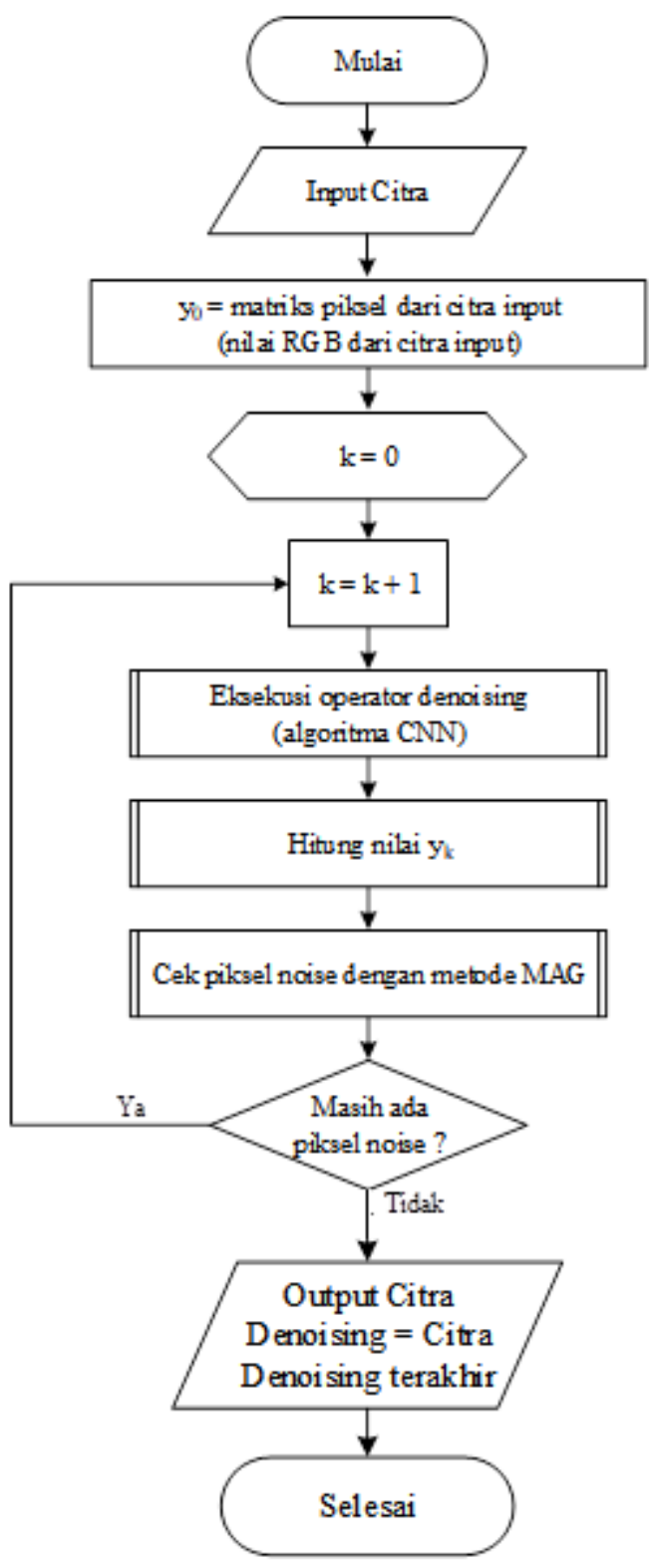

(a). Flowchart IDBP-CNN

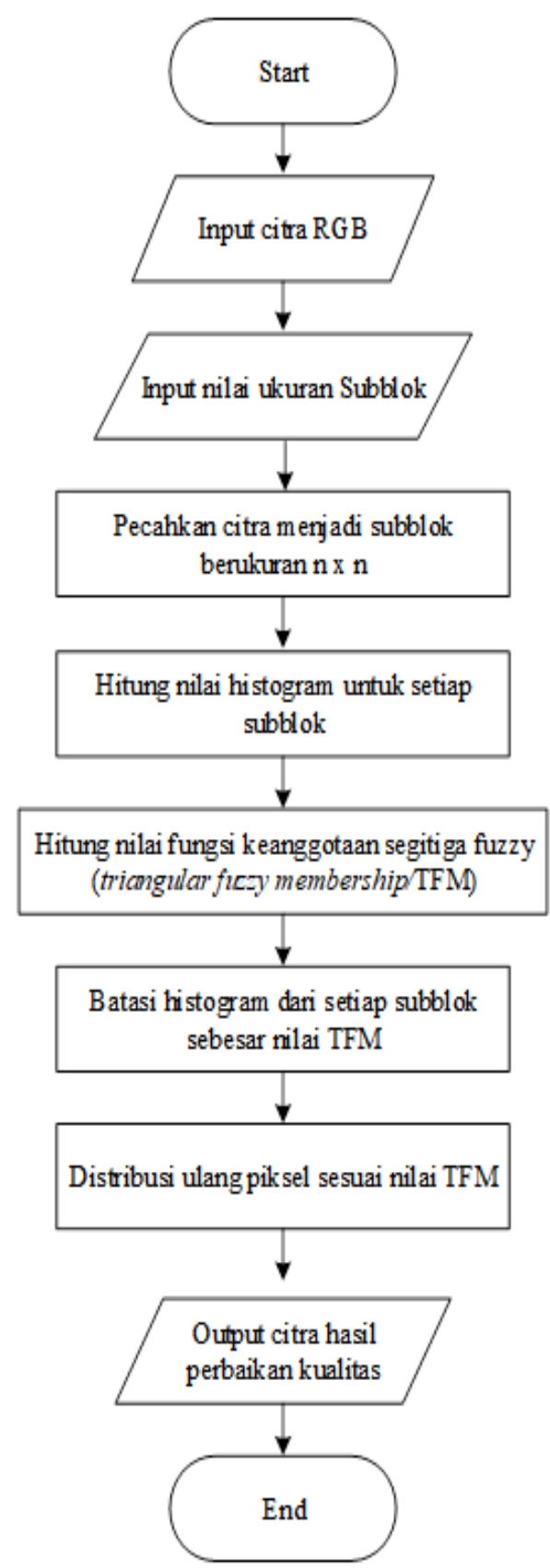

(b). Flowchart TFM-CLAHE

Gambar 4 Flowchart algoritma peningkatan kualitas citra

Untuk citra yang sudah ditambahkan noise berikutnya dapat dilakukan proses reduksi noise (denoising) dengan $\mathrm{T}=192$, kemudian citra hasilnya disimpan untuk dilanjutkan ke algoritma berikutnya, prosesnya seperti pada Gambar 5 di bawah. 


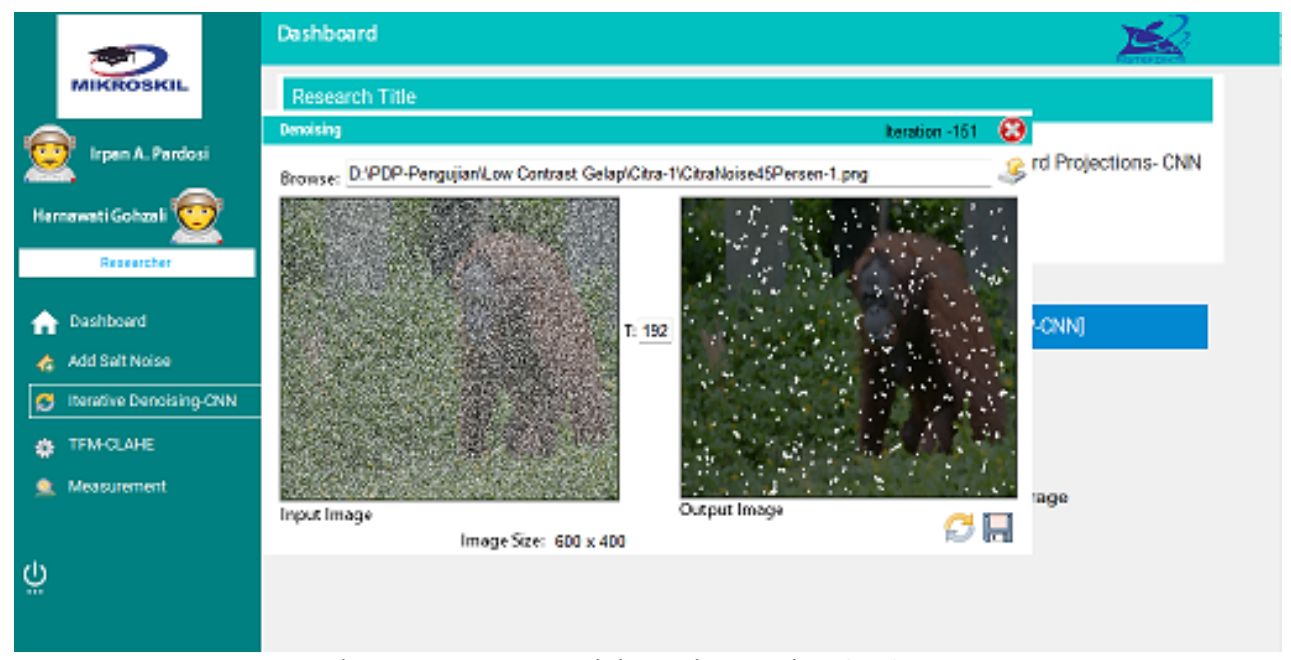

Gambar 5 Proses Denoising Citra Noise 45\%

Jika proses denoising sudah selesai tahapan berikutnya diproses ke algoritma peningkatan kontras menggunakan TFM-CLAHE seperti pada Gambar 6 di bawah dan menyimpan citra hasil untuk berikutnya dilakukan pengukuran kualitas citra hasil.

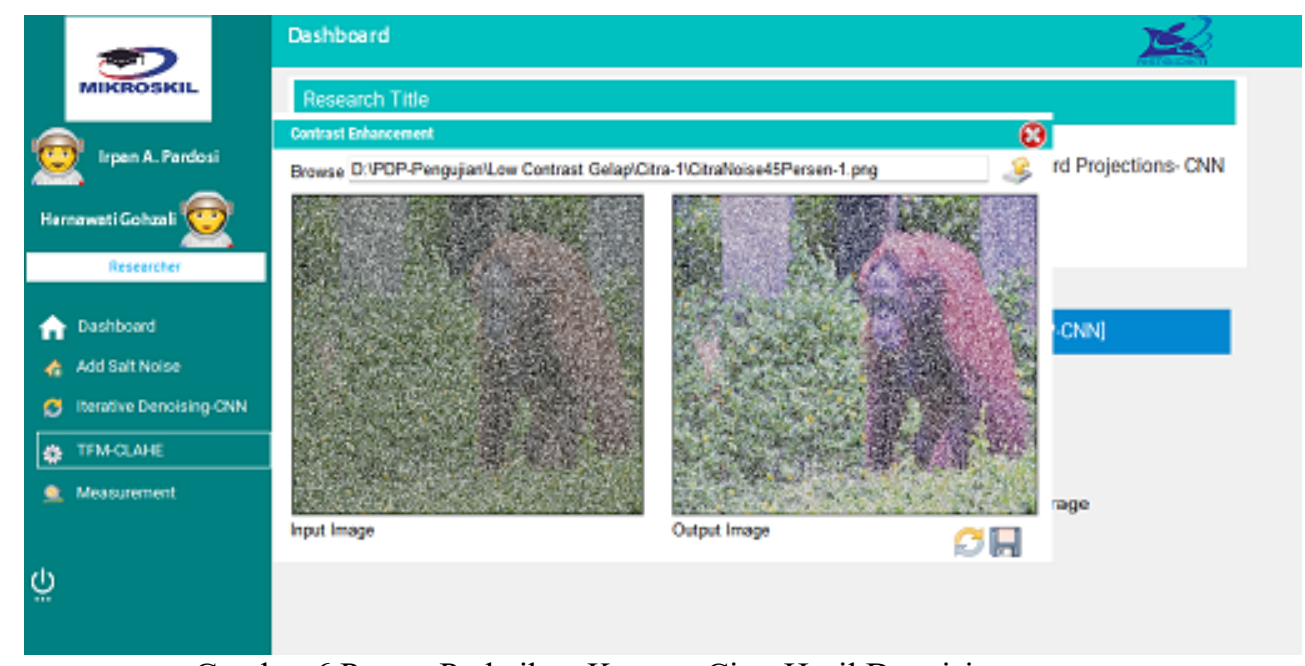

Gambar 6 Proses Perbaikan Kontras Citra Hasil Denoising

Kombinasi urutan dari kedua algoritma di atas juga dilakukan sebaliknya untuk masingmasing 10 citra uji yang sudah ditambahkan noise $45 \%$ dimulai dari proses peningkatan kontras seperti Gambar 6, lalu kemudian citra hasilnya direduksi noise seperti Gambar 5, kemudian setelah dilakukan kedua proses di atas, berikutnya citra hasil kombinasi kedua algoritma itu diukur kualitasnya menggunakan algoritma MSE, PSNR dan SE (Shannon Entropy) seperti Gambar 7 di bawah ini. 


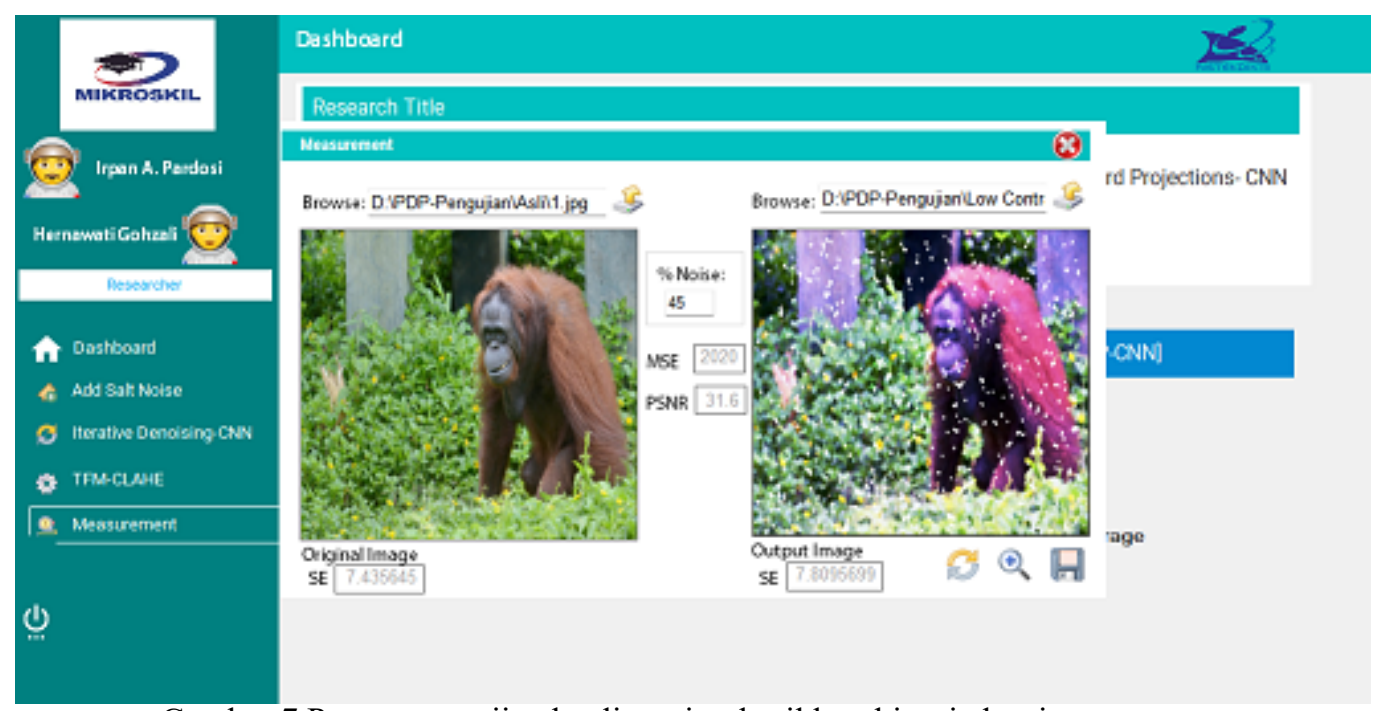

Gambar 7 Proses pengujian kualitas citra hasil kombinasi algoritma

Dari hasil pengujian pertama, dilakukan untuk mendapatkan kombinasi paling optimal untuk memperbaiki kualitas citra dengan mereduksi noise dan memperbaiki kontras citra rendah dan sebaliknya, kemudian citra noise dan citra hasil perbaikan kontras dibandingkan dengan citra asli dan hasilnya dijabarkan seperti Tabel 2 di bawah.

Tabel 2 Hasil Pengujian Kombinasi Kedua Algoritma

\begin{tabular}{|r|l|r|r|r|r|r|r|}
\hline \multirow{2}{*}{ No } & \multirow{2}{*}{ Nama Citra } & \multicolumn{2}{|c|}{ Citra Noise 45 Persen } & \multicolumn{2}{|c|}{$\begin{array}{c}\text { IDBP-CNN + } \\
\text { CLAHE }\end{array}$} & \multicolumn{1}{c|}{ TFM- } & \multicolumn{2}{c|}{ TFM-CLAHE + IDBP- } \\
CNNN
\end{tabular}

Dari Tabel 2 di atas berdasarkan nilai PSNR rata-rata kualitas citra paling baik adalah kombinasi algoritma TFM-CLAHE +IDBP-CNN $=31.69 \mathrm{~dB}$ lebih baik dibandingkan sebaliknya $31.10 \mathrm{~dB}$, dari 10 citra uji hanya 2 citra yaitu Citra-5 dan Citra-6 yang tidak lebih baik nilainya, persentase peningkatan kualitas citra didapatkan selisih $31.69-27.68=4.01$, sehingga persentase peningkatan kualitas citra didapatkan $(4.01 / 27.68) * 100=14.50 \%$, secara grafik digambarkan seperti Gambar 8 di bawah. 


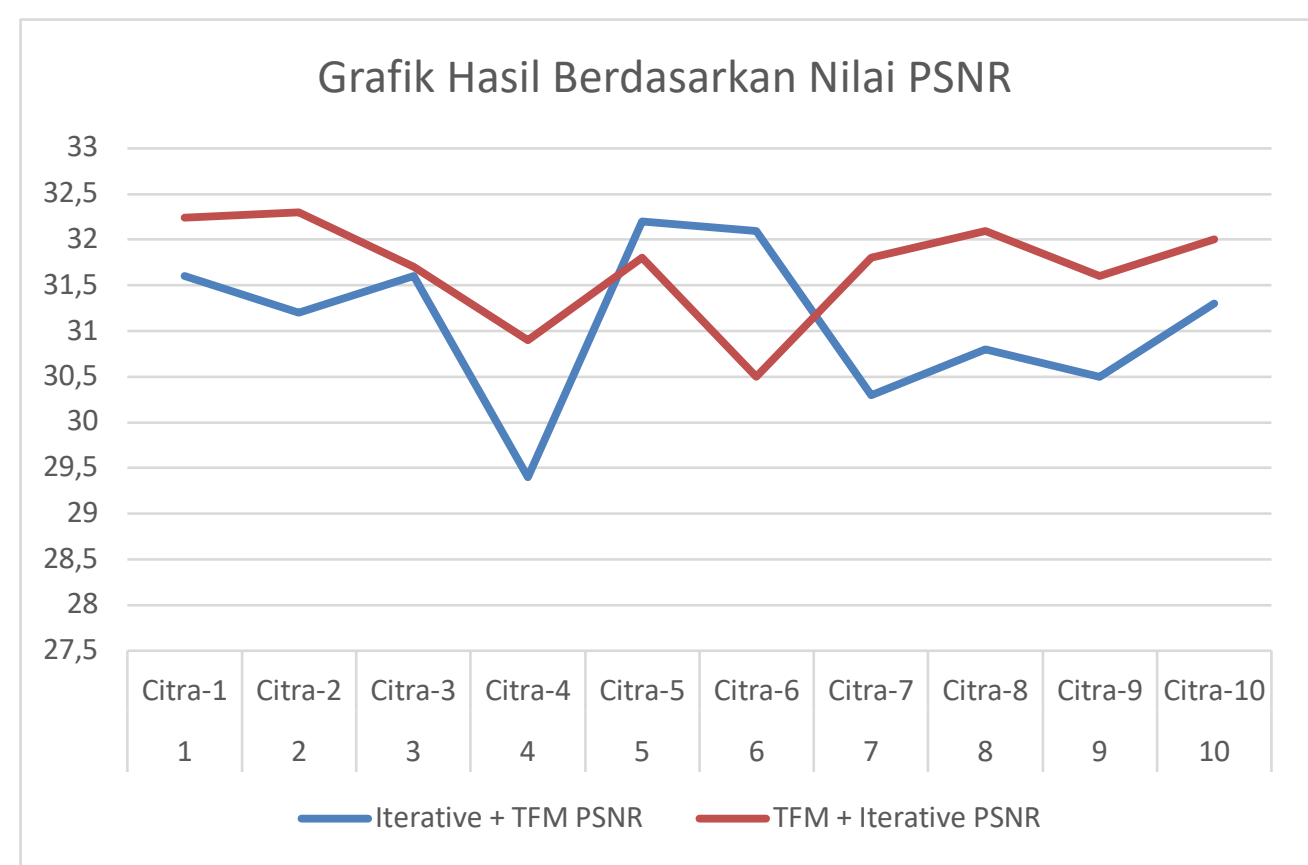

Gambar 8 Grafik Hasil Kualitas Citra Berdasarkan Nilai PSNR

Untuk pengujian kedua mengenai keberagaman informasi setelah proses perbaikan citra didapatkan hasil seperti tabel 3 di bawah, secara keseluruhan kombinasi IDBP-CNN + TFM$C L A H E$ lebih baik dibandingkan sebaliknya dengan rata-rata nilai $\mathrm{SE}=7.8355$ dengan selisih paling sedikit sebesar $0.2849(3.77 \%)$ terhadap citra asli sedangkan kombinasi TFM-CLAHE + $I D B P-C N N$ sebesar 7.1874 dengan selisih $=0.3632(4.81 \%)$

Tabel 3 Hasil pengujian kombinasi algoritma dengan Shannon Entropy (SE)

\begin{tabular}{|c|c|c|c|c|}
\hline \multirow{2}{*}{ No } & \multirow{2}{*}{ Nama Citra } & \multirow{2}{*}{ SE Citra Asli } & $\begin{array}{l}\text { IDBP-CNN + TFM- } \\
\text { CLAHE }\end{array}$ & $\begin{array}{l}\text { TFM-CLAHE + } \\
\text { IDBP-CNN }\end{array}$ \\
\hline & & & SE & SE \\
\hline 1 & Citra-1 & 7.4356 & 7.8096 & 7.1869 \\
\hline 2 & Citra-2 & 7.5196 & 7.8440 & 7.2253 \\
\hline 3 & Citra-3 & 7.5460 & 7.8626 & 7.1963 \\
\hline 4 & Citra-4 & 7.4972 & 7.8677 & 7.1742 \\
\hline 5 & Citra-5 & 7.5137 & 7.7594 & 7.1210 \\
\hline 6 & Citra-6 & 7.6595 & 7.8495 & 7.2212 \\
\hline 7 & Citra-7 & 7.5903 & 7.8397 & 7.2212 \\
\hline 8 & Citra-8 & 7.6357 & 7.8458 & 7.2031 \\
\hline 9 & Citra-9 & 7.7210 & 7.8561 & 7.1342 \\
\hline 10 & Citra-10 & 7.3869 & 7.8208 & 7.1902 \\
\hline Rata & rata & 7.5506 & 7.8355 & 7.1874 \\
\hline
\end{tabular}

Hasil pengujian kedua mengenai keberagaman informasi citra hasil setelah dilakukan perbaikan citra dan dibandingkan dengan citra asli dapat terlihat secara grafik seperti gambar 9 di bawah ini. 


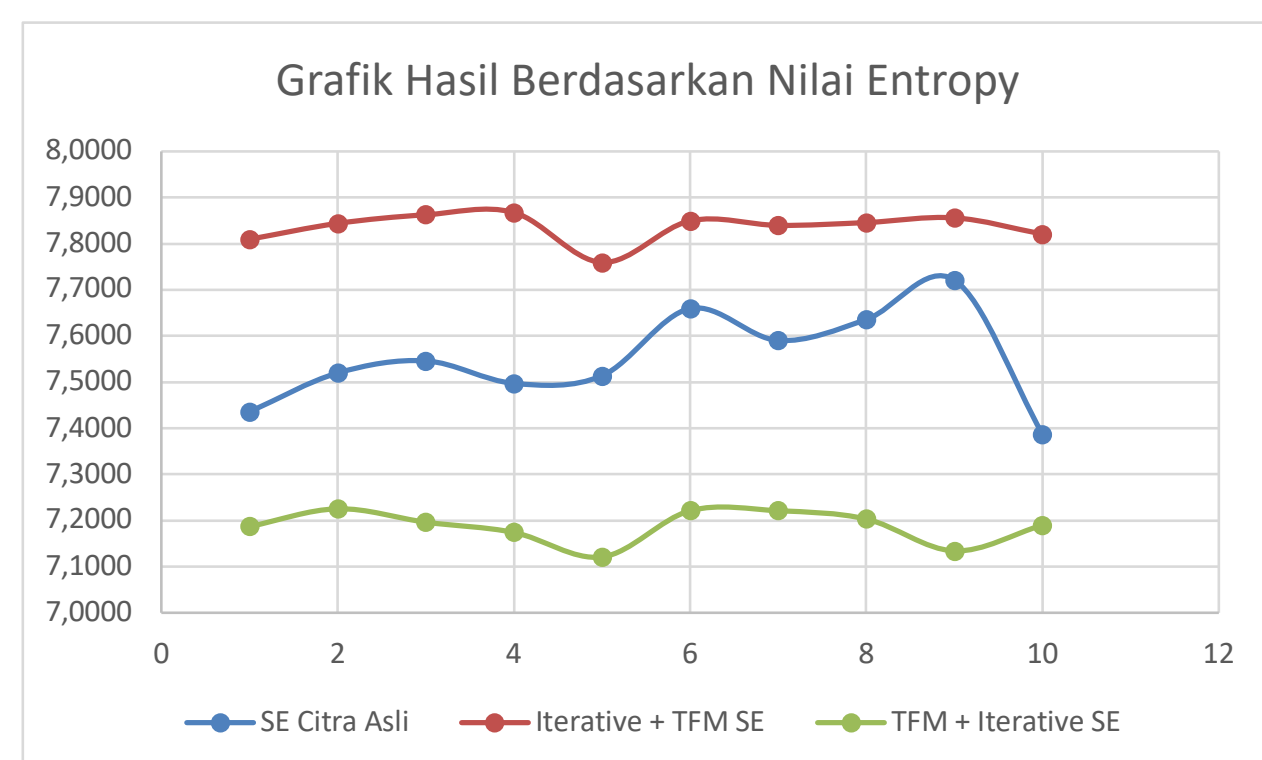

Gambar 9 Grafik Hasil Kombinasi Algoritma Keberegaman informasi Citra Hasil

\section{KESIMPULAN DAN SARAN}

Berdasarkan pengujian yang sudah dilakukan terhadap citra kontras rendah gelap dengan persentase noise sebesar $45 \%$ didapatkan beberapa kesimpulan sebagai berikut:

1. Kombinasi paling optimal untuk meningkatkan kualitas citra diawali dengan TFM-Clahe kemudian diikuti IDBP-CNN dengan rata-rata PSNR $=31.69 \mathrm{~dB}$ dibandingkan kombinasi sebaliknya $31.1 \mathrm{~dB}$.

2. Peningkatan kualitas citra yang dihasilkan dari citra noise sebesar $45 \%$ yang memiliki rata-rata $\mathrm{PSNR}=27,68$, meningkat sebesar $14,50 \%$ menjadi rata-rata $\mathrm{PSNR}=31.694 \mathrm{db}$

3. Persentase keragaman informasi dari kombinasi algoritma IDBP-CNN kemudian diikuti TFM-CLAHE justru lebih baik dengan rata-rata keragaman informasi dibandingkan citra asli dengan selisih $3.77 \%$ dan kombinasi sebaliknya selisih $4.81 \%$

Dari hasil penelitian juga didapatkan kalau pengujian terhadap citra kontras rendah ada perbedaan hasil pada 2 citra yaitu citra-5 dan citra-6 dengan proses iterasi denoising yang lebih singkat, sehingga perlu juga dilakukan kajian lanjutan dan pengujian untuk kontras rendah cerah dan metode lainnya untuk mendapatkan kualitas PSNR lebih baik mendekati 40dB untuk noise 55\% untuk mendapatkan hasil optimal dan lebih luas dari kedua kombinasi tersebut.

\section{UCAPAN TERIMA KASIH}

Peneliti mengucapkan terimakasih kepada Kementerian Riset dan Teknologi / Badan Riset dan Inovasi Nasional (RistekBRIN) yang mendanai penelitian ini dari awal hingga selesai ke tahapan publikasi.

\section{DAFTAR PUSTAKA}

[1] J. R. Tang and N. A. M. Isa, "An adaptive fuzzy contrast enhancement algorithm with details preserving," J. ICT Res. Appl., vol. 8c, no. 2, pp. 126-140, 2014.

[2] A. K. Gupta, "Low Contrast Image Enhancement Technique By Using Fuzzy Method," Int. J. Eng. Res. Gen. Sci., vol. 4, no. 2, pp. 518-526, 2016.

[3] M. Pitchammal, S. S. Nisha, and M. M. Sathik, "Noise Reduction in MRI Neck Image Using Adaptive Fuzzy Filter in Contourlet Transform," Int. J. Eng. Sci. Comput., vol. 6, 
no. 3, pp. 2478-2484, 2016.

[4] S. Gupta and R. K. Sunkaria, "Real-time salt and pepper noise removal from medical images using a modified weighted average filtering," 2017 th Int. Conf. Image Inf. Process. ICIIP 2017, vol. 2018-Maret, pp. 238-243, 2018.

[5] T. Gebreyohannes, "Adaptive Noise Reduction Scheme for Salt and Pepper," Signal Image Process. An Int. J., vol. 2, no. 4, pp. 47-55, 2011.

[6] E. J. Leavline and D. A. A. G. Singh, "Salt and Pepper Noise Detection and Removal in Gray Scale Images: An Experimental Analysis," Int. J. Signal Process. Image Process. Pattern Recognit., vol. 6, no. 5, pp. 343-352, 2013.

[7] I. A. Pardosi and A. A. Lubis, "Analisis Kualitas Citra Hasil Reduksi Noise Menggunakan Spatial Median Filter dan Adaptive Fuzzy Filter Terhadap Variasi Kedalaman Citra," Indones. J. Inf. Syst., vol. 1, no. 2, p. 78, 2019.

[8] R. C. Gonzalez, R. E. Woods, and B. R. Masters, "Digital Image Processing, Third Edition," J. Biomed. Opt., vol. 14, no. 2, p. 029901, 2009.

[9] I. A. Pardosi et al., "Restorasi Citra Digital Menggunakan Iterative Denoising dan Backward Projections with CNN," SIFO Mikroskil, vol. 21, no. 1, pp. 37-50, 2020.

[10] I. A. Pardosi, P. Sirait, S. Goh, and R. Chandra, "Perbaikan Citra Gelap dan Pembesaran Objek Citra Menggunakan Gradient Based Low-Light Image Enhancement dan Rational Ball Cubic B-Spline With Genetic Algorithm," J. SIFO Mikroskil, vol. Vol. 20 No, no. 2, pp. 105-115, 2019.

[11] B. Sree Vidya and E. Chandra, "Triangular Fuzzy Membership-Contrast Limited Adaptive Histogram Equalization (TFM-CLAHE) for Enhancement of Multimodal Biometric Images," Wirel. Pers. Commun., vol. 106, no. 2, pp. 651-680, 2019.

[12] L. Sitorus, Daniel, N. P. Wong, and I. Pardosi, "Big Data in Pandemic Phase: Innovation and Implementation," in SEMINAR NASIONAL ILMU KOMPUTER (sniKom 2020), 2020, vol. 148, pp. 364-372.

[13] T. Tirer and R. Giryes, "Image Restoration by Iterative Denoising and Backward Projections," IEEE Trans. Image Process., vol. 28, no. 3, pp. 1220-1234, 2018.

[14] J. Al-Azzeh, B. Zahran, and Z. Alqadi, "Salt and pepper noise: Effects and removal," Int. J. Informatics Vis., vol. 2, no. 4, pp. 252-256, 2018.

[15] J. C. M. Román, J. L. V. Noguera, H. Legal-Ayala, D. P. Pinto-Roa, S. Gomez-Guerrero, and M. G. Torres, "Entropy and contrast enhancement of infrared thermal images using the multiscale top-hat transform," Entropy, vol. 21, no. 3, pp. 1-19, 2019. 